\title{
Isolasi dan Identifikasi Bakteri Resisten Merkuri melalui Analisis Gen 16S rRNA pada Urin Pasien dengan Tumpatan Amalgam
}

\author{
${ }^{1}$ Eunike M. Karamoy \\ ${ }^{2}$ Fatimawali \\ ${ }^{2}$ Billy J. Kepel
}

\author{
${ }^{1}$ Program Studi Pendidikan Dokter Fakultas Kedokteran Universitas Sam Ratulangi Manado \\ ${ }^{2}$ Bagian Kimia Fakultas Kedokteran Universitas Sam Ratulangi Manado \\ Email: eunikekaramoy@gmail.com
}

\begin{abstract}
Mercury is a hazardous metal used as the main component of amalgam. Amalgam is a source of the chronic exposure of elemental mercury $\left(\mathrm{Hg}^{0}\right)$ to human body. In the body, mercury is excreted through urine. Chronic exposure to mercury causes bacteria to develop resistance using mer operon. By analyzing the $16 \mathrm{~S}$ rRNA gene, the bacterial identification is more specific and able to facilitate further studies about mercury-resistant bacteria within the human body. This study was aimed to identify the mercury-resistant bacteria isolated from the urine of patients with dental amalgam. This was an explorative descriptive study by isolation and identification of mercury-resistant bacteria in the urine samples of patients with dental amalgam and studying the evolutionary relationship through 16S rRNA gene. The nucleotide sequence of $16 \mathrm{~S}$ rRNA gene of bacteria from urine samples of patients with dental amalgam showed 100\% resemblances with Bacillus cereus. The phylogenetic tree showed that Bacillus cereus was closely related to Bacillus anthracis, Bacillus sp., and Bacillus thuringiensis. Conclusion: Mercury-resistant bacteria isolated from urine of patients with dental amalgam was Bacillus cereus, which was not the normal flora of human body. Bacillus cereus had close evolutionary relationship with Bacillus anthracis, Bacillus sp., and Bacillus thuringiensis.
\end{abstract}

Keywords: mercury-resistant bacteria, 16S rRNA gene, urine, amalgam.

\begin{abstract}
Abstrak: Merkuri adalah logam berbahaya komponen utama pada amalgam. Amalgam merupakan sumber paparan kronis merkuri elemental $\left(\mathrm{Hg}^{0}\right)$ pada manusia. Di dalam tubuh, merkuri diekskresikan melalui urin. Akibat terpapar merkuri dalam waktu lama, bakteri dalam urin mengembangkan mekanisme resistensi terhadap merkuri melalui operon mer. Melalui analisis gen 16S rRNA, identifikasi bakteri lebih spesifik sehingga mempermudah untuk mempelajari dan meneliti lebih lanjut tentang bakteri resisten merkuri pada tubuh manusia. Penelitian ini bertujuan untuk mengetahui jenis bakteri resisten merkuri yang diisolasi dari urin pasien dengan tumpatan amalgam. Jenis penelitian ialah deskriptif eksploratif, melalui isolasi dan identifikasi bakteri resisten merkuri dari urin pasien pengguna amalgam serta melihat hubungan kekerabatan bakteri tersebut melalui gen 16S rRNA. Hasil penelitian mendapatkan urutan nukleotida gen 16S rRNA bakteri dari urin pasien pengguna amalgam memiliki kesamaan $100 \%$ paling banyak dengan Bacillus cereus. Berdasarkan analisis hubungan kekerabatan, Bacillus cereus berkerabat dekat dengan Bacillus anthracis, Bacillus $s p$, dan Bacillus thuringiensis. Simpulan: Bakteri resisten merkuri yang diisolasi dari sampel urin pasien pengguna amalgam ialah Bacillus cereus, yang bukan merupakan flora normal tubuh manusia. Bacillus cereus memiliki hubungan kekerabatan dekat dengan Bacillus anthracis, Bacillus sp, dan Bacillus thuringiensis.
\end{abstract}

Kata kunci: bakteri resisten merkuri, gen 16S rRNA, urin, amalgam 
Merkuri (Hg) merupakan unsur logam berbahaya yang mempunyai tiga bentuk, yaitu elemental $\left(\mathrm{Hg}^{0}\right)$, anorganik $\left(\mathrm{Hg}^{+}\right.$dan $\mathrm{Hg}^{2+}$ ), dan organik (metilmerkuri dan etilmerkuri) dengan toksisitas dan sumber paparan yang berbeda-beda. ${ }^{1-6}$

Amalgam adalah campuran beberapa logam dengan 50\% komponennya ialah merkuri. ${ }^{6-8}$ Amalgam telah digunakan selama lebih dari 150 tahun untuk restorasi gigi karies karena murah, mudah, kuat, serta tahan lama. ${ }^{8,9}$ Menurut American Dental Association, terdapat 100 juta pengguna amalgam di Amerika Serikat. ${ }^{9}$ Pada tahun 2014, tumpatan amalgam digunakan pada 250 pasien $(62,5 \%)$ dari total 400 pasien restorasi gigi di Rumah Sakit Gigi dan Mulut Manado, ${ }^{10}$ sedangkan pada tahun 2016, tumpatan amalgam digunakan di Puskesmas Bahu Manado dengan jumlah pasien 84 orang. ${ }^{11}$

Merkuri bersifat toksik, khususnya pada sistem saraf pusat dan ginjal. Merkuri mudah diserap dalam darah dan berbagai jaringan tubuh, serta dapat menembus sawar darah otak dan sawar uri. Efek toksik merkuri berdampak pada berbagai sistem organ. $^{2-8,12}$ Ketiga bentuk merkuri dalam tubuh, sebagian besar diekskresikan melalui feses dan urin. ${ }^{3-5}$

Merkuri merupakan polutan bagi lingkungan, sehingga diperlukan suatu agen untuk proses remediasi. ${ }^{5,13,14}$ Bakteri resisten merkuri banyak diteliti dalam rangka pemanfaatannya sebagai agen bioremediasi. ${ }^{3,5}$ Kemampuan resistensi merkuri oleh bakteri diatur oleh operon mer, yang terdiri dari gen merA yang mengkode enzim merkuri reduktase dan gen merB yang mengkode enzim organomerkuri liase, serta berbagai promoter, regulator, dan operator. ${ }^{5}$

Berbagai penelitian telah mengidentifikasi bakteri resisten merkuri dari air dan tanah yang tercemar merkuri, serta feses dan urin pasien pengguna amalgam. Berdasarkan hasil-hasil yang d, disimpulkan bahwa koloni bakteri yang ada pada suatu komunitas, beradaptasi terhadap polutan yaitu merkuri, melalui mekanisme resistensi, atau yang dikenal sebagai pollution-induced community tolerance (PICT). ${ }^{13-22}$

Metode identifikasi yang dilakukan adalah uji biokimia (konvensional) atau secara biomolekuler melalui analisis gen 16S rRNA bakteri. Pada uji biokimia, dilakukan beberapa uji dan hasilnya dicocokkan dengan karakteristik bakteri pada Bergey's Manual of Systematic Bacteriology. Sayangnya metode ini memerlukan waktu yang lama, serta sangat tergantung pada ketepatan pengamatan dari peneliti. Selain itu, metode ini hanya dapat mengidentifikasi bakteri sampai tingkat genus. $^{23,24}$

Gen 16S rRNA merupakan komponen yang lestari dengan pola perubahan yang lambat, sehingga dapat digunakan untuk menilai hubungan kekerabatan genetik antar spesies bakteri. ${ }^{25-28}$ Metode ini memakai alat yang lebih canggih serta sangat memerlukan keterampilan operator. Hasil sekuensing segmen gen ini spesifik untuk setiap spesies bakteri sehingga, metode ini lebih akurat dan kesalahan identifikasi pada metode konvensional dapat dihindari. ${ }^{23,24}$

Penggunaan amalgam merupakan sumber paparan kronis merkuri bagi manusia. Merkuri yang masuk ke dalam tubuh diekskresikan melalui urin. Dengan melakukan isolasi dan identifikasi secara spesifik bakteri resisten merkuri pada urin, kita dapat mengetahui apakah bakteri tersebut tergolong flora normal dalam tubuh. Selanjutnya, dapat dilakukan penelitian tentang pengaruh bakteri tersebut bagi tubuh dan kemungkinan penggunaannya dalam bioremediasi lingkungan yang tercemar merkuri.

Penelitian ini bertujuan untuk mengetahui jenis bakteri resisten merkuri yang diisolasi dari urin pasien dengan tambalan amalgam melalui analisis gen $16 \mathrm{~S}$ rRNA.

\section{BAHAN DAN CARA KERJA}

Jenis penelitian ini ialah deskriptif eksploratif yang dilaksanakan pada bulan September - Desember 2017. Penelitian dilakukan di Laboratorium Mikrobiologi 
dan Biomolekuler Program Studi Farmasi FMIPA UNSRAT. Populasi penelitian ini yaitu populasi bakteri yang diambil dari urin pasien dengan tumpatan amalgam. Sampel penelitian yang digunakan ialah isolat bakteri yang tumbuh pada media nutrient broth (NB) yang mengandung $\mathrm{HgCl}_{2}$ atau lebih. Variabel penelitian ini ialah jenis bakteri resisten merkuri pada urin pasien dnengan tumpatan amalgam yang diidentifikasi melalui analisis gen 16S rRNA.

\section{Bahan isolasi DNA plasmid dan analisis gen 16S rRNA}

Kit innuPREP DNA Micro-Kit (Biometra): EDTA, lytic enzyme, larutan nuclei lysis, larutan RNAase, larutan protein precipitation, isopropanol, etanol $70 \%$, larutan DNA rehydration, primer Bact-FI (forward) 5'- AGA GTT TGA TCM TGG CTC AG -3' dan Uni-B1 (reverse) 5'- GGT TAC STT GTT ACG ACT $\mathrm{T}-3$ ' (Eurogenetic AIT), agarose (Vivantis), etidium bromide, loading dye (Vivantis), dan marker.

\section{Isolasi DNA genomik}

Sampel bakteri yang ditumbuhkan dari media agar miring diambil satu öse dan dimasukkan ke dalam tabung reaksi berisi media Luria Berthani (LB) cair $10 \mathrm{~mL}$ dan diinkubasi selama $1 \times 24$ jam. Diambil $2 \mathrm{~mL}$ sampel ke dalam tabung Eppendorf, kemudian disentrifus dengan kecepatan $7.500 \mathrm{rpm}$ selama 10 menit, supernatan dibuang.

Lisis: Tambahkan $200 \mu \mathrm{L}$ TLS dan 20 $\mu \mathrm{L}$ PK, divortex selama 5 detik, kemudian inkubasi pada suhu $50^{\circ} \mathrm{C}$ selama 10 menit. Pengikatan DNA: Tambahkan $200 \mu \mathrm{L}$ TBS, kemudian divortex. Pasangkan tabung Spin Filter dengan Receiver Tube. Masukkan sampel ke dalam tabung Spin Filter, kemudian sentrifus dengan kecepatan $12.000 \mathrm{rpm}$ selama 3 menit. Pencucian: Tambahkan $400 \mu \mathrm{L}$ HS, sentrifus dengan kecepatan $12.000 \mathrm{rpm}$ selama 3 menit. Kemudian, tambahkan $750 \mu \mathrm{L}$ MS dan disentrifus dengan kecepatan $12.000 \mathrm{rpm}$ selama 3 menit. Filtrat dibuang, kemudian disentrifus lagi dengan kecepatan 14.000 rpm selama 2 menit. Elusi: Masukkan tabung Spin Filter ke tabung Eppendorf (tabung Elusi), tambahkan 50-100 $\mu \mathrm{L}$ buffer elusi. Inkubasi selama 1 menit pada suhu kamar, kemudian sentrifus dengan kecepatan 8.000 rpm selama 2 menit.

\section{Amplifikasi gen 16S rRNA dengan teknik PCR}

Amplifikasi dilakukan dengan menggunakan mesin PCR Biometra TPersonal. Primer yang digunakan yaitu pasangan primer universal Bact F1 (forward) dan Uni B1 (reverse). Cetakan yang digunakan untuk amplifikasi adalah DNA plasmid bakteri yang telah diisolasi. Amplifikasi dengan teknik PCR dilakukan dengan variasi komponen reagen dan kondisi reaksi PCR seperti berikut:

Komposisi reagen untuk PCR $16 S$ rRNA

Untuk 1 tabung PCR: $\mathrm{ddH}_{2} \mathrm{O} 12,0 \mu \mathrm{L}$, 5x FIREPol $^{\circledR}$ Master Mix 4,0 $\mu \mathrm{L}$, Primer UniBI $30 \mathrm{pmol} / \mu \mathrm{L} 1,0 \mu \mathrm{L}$, Primer BactFI $30 \mathrm{pmol} / \mu \mathrm{L} 1,0 \mu \mathrm{L}$, Templat $2,0 \quad \mu \mathrm{L}$, sehingga total dalam 1 tabung terdapat 20,0 $\mu \mathrm{L}$

Kondisi reaksi PCR gen $16 S$ rRNA

Denaturasi awal $95^{\circ} \mathrm{C} 180$ detik, Denaturasi $95^{\circ} \mathrm{C} 30$ detik, Annealing $50^{\circ} \mathrm{C}$ 30 detik, Polimerasi $72^{\circ} \mathrm{C} 90$ detik, dan Pemantapan $72^{\circ} \mathrm{C}$ selama 60 detik. Keseluruhannya dijalankan dalam 35 siklus.

Elektroforesis gel agarose $1 \%$ dan visualisasi gen $16 \mathrm{~S}$ rRNA

DNA yang telah diamplifikasi diseparasi dengan elektroforesis gel agarose $1 \%$, kemudian divisualisasikan menggunakan pewarna etidium bromida dan dideteksi dengan sinar UV pada $U V$ transiluminator. Hasil foto dipakai untuk menentukan pola pita.

\section{Sekuensing dan analisis gen 16S rRNA}

Sekuensing dilakukan untuk menentukan urutan nukleotida pada fragmen DNA yang telah diamplifikasi dan divisualisasi menggunakan mesin sekuensing DNA otomatis. Proses sekuensing dilakukan di 
PT. Genetika Science Indonesia.

Hasil sekuensing DNA berupa urutan nukleotida gen $16 \mathrm{~S}$ rRNA diolah menggunakan program Geneious 10.2.3 menjadi format FASTA, kemudian dilakukan proses BLAST melalui situs: https://blast.ncbi.nlm.nih.gov/Blast.cgi.

Hasil BLAST akan menunjukkan kesamaan antara urutan nukleotida gen $16 \mathrm{~S}$ rRNA isolat yang diperoleh dengan urutan nukleotida gen $16 \mathrm{~S}$ rRNA bakteri yang ada pada GenBank.

Setelah jenis bakteri diidentifikasi, dilakukan analisis hubungan kekerabatan antara isolat dan jenis-jenis bakteri lain yang memiliki kesamaan dengan sampel yang ada. Metode yang dipakai yaitu dengan multiple sequence alignment secara daring, menggunakan program Clustal Omega yang dapat diakses melalui tautan https://www.ebi.ac.uk/Tools/msa/clustalo/ untuk mendapatkan hasil alignment dan pohon filogenetik.

\section{HASIL PENELITIAN}

DNA genomik yang telah diisolasi dan diekstraksi dari isolat FUA kemudian diamplifikasi dengan PCR menggunakan primer universal untuk gen 16S rRNA Bact-FI (Forward) 5' - AGA GTT TGA TCM TGG CTC AG -3' dan Uni-B1 (Reverse) 5'- GGT TAC STT GTT ACG ACT T -3' (Eurogenetic AIT) yang dapat mengamplifikasi gen 16S rRNA sepanjang 1500 bp. Hasil amplifikasi kemudian dilakukan elektroforesis dan divisualisasi dengan sinar UV. Hasil elektroforesis ditampilkan pada Gambar 1.

Pada Gambar 1 terlihat bahwa hasil amplifikasi gen 16S rRNA isolat bakteri dengan PCR nampak jelas pada pita 1.500 bp. Untuk mengetahui urutan nukleotida dari DNA, hasil amplifikasi dilakukan proses sekuensing. Hasil sekuensing gen terdiri dari forward dan reverse, sesuai dengan primer yang digunakan.

Dengan menggunakan program Geneious 10.2.3, hasil sekuensing forward dan reverse dilakukan proses alignment untuk mendapatkan consensus sequence. Kromatogram hasil proses alignment kemudian dilakukan proses trimming, untuk membuang bagian awal dan akhir sekuensing yang buruk. Hasil sekuens yang telah ditrimming disalin menjadi urutan nukleotida, kemudian dilakukan proses BLAST. Hasil BLAST isolat FUA ditunjukkan pada Tabel 1.

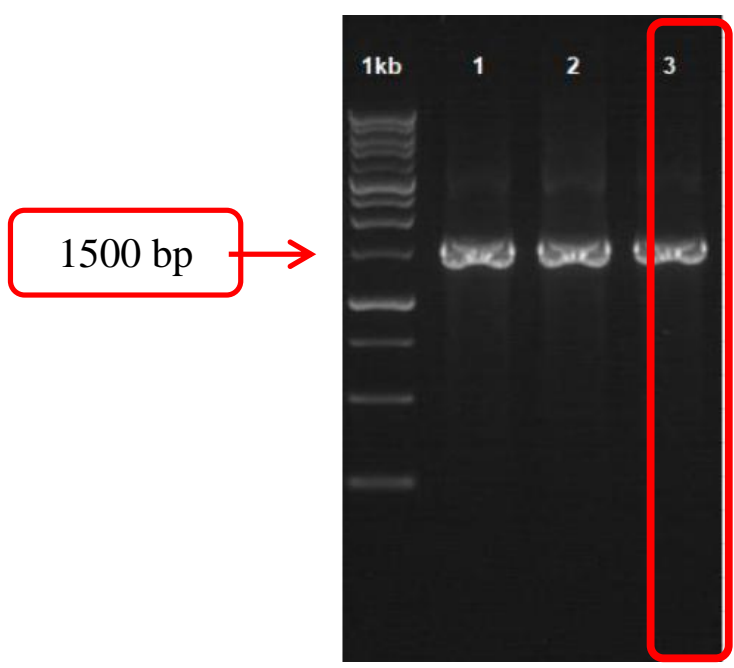

Gambar 1. Elektroforegram fragmen gen 16S rRNA hasil amplifikasi DNA dengan PCR. Isolat FUA berada pada Lajur (3)

Tabel 1. Hasil BLAST gen 16S rRNA Isolat FUA.

\begin{tabular}{clcc}
\hline No & $\begin{array}{c}\text { Deskripsi } \\
\text { spesies }\end{array}$ & $\begin{array}{c}\text { Max. } \\
\text { Identitiy }\end{array}$ & Coverage \\
\hline 1. & $\begin{array}{l}\text { Bacillus } \\
\text { cereus }\end{array}$ & $100 \%$ & $100 \%$ \\
2. & Bacillus sp. & $100 \%$ & $100 \%$ \\
3. & $\begin{array}{l}\text { Bacillus } \\
\text { thuringiensis }\end{array}$ & $100 \%$ & $100 \%$ \\
4. & $\begin{array}{l}\text { Bacillus } \\
\text { anthracis. }\end{array}$ & $100 \%$ & $100 \%$ \\
\hline
\end{tabular}

Berdasarkan hasil BLAST, isolat FUA mempunyai kesamaan $100 \%$ dengan bakteri Bacillus cereus. Setelah itu, dicari hubungan kekerabatan antara isolat FUA dengan bakteri genus Bacillus lainnya yang cocok berdasarkan hasil BLAST. Hubungan kekerabatan antara spesies dicari menggunakan metode multiple sequence alignment (MSA) menggunakan program Clustal Omega.

Pohon filogenetik yang menunjukkan hubungan kekerabatan antara berbagai 
spesies Bacillus dengan isolat FUA ditunjukkan pada Gambar 2.

Berdasarkan analisis hubungan kekerabatan, isolat FUA yang telah teridentifikasi sebagai Bacillus cereus memiliki hubungan yang dekat dengan Bacillus anthracis, Bacillus sp. dan Bacillus thuringiensis.

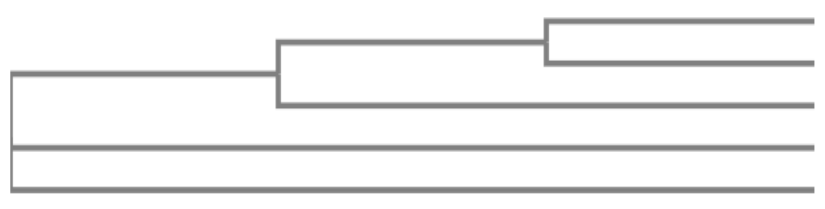

Bacillus cereus strain DM- 50.01112

FUA assemble $\bar{d}-0.01 \overline{1} 12$

Bacillus_anthracis_strain_MKR-9 0.00662

Bacillus_sp_strain_DIB76BC1 0.00079

Bacillus_thuringiensis_strain_PM-1 0.00074

Gambar 2. Pohon filogenetik isolat FUA

\section{BAHASAN}

Kemampuan bakteri untuk resisten terhadap merkuri diregulasi oleh operon mer, yang dapat terletak di berbagai tempat seperti plasmid, DNA genomik, transposon, dan integrin. ${ }^{5,14,29}$ Terdapat dua jenis gen utama pada operon mer yang menentukan sifat resistensi merkuri pada bakteri, yaitu merA dan merB. Jika suatu bakteri hanya mengekspresikan gen merA saja, maka disebut bakteri resisten merkuri spektrum sempit. Jika bakteri dapat mengekspresikan gen merA dan gen merB, maka disebut bakteri resisten merkuri spektrum luas. ${ }^{5}$

Berdasarkan analisis gen 16S rRNA bakteri resisten merkuri pada urin pasien pengguna amalgam, didapatkan kemiripan $100 \%$ dengan bakteri Bacillus cereus, dimana bakteri ini bukan termasuk flora normal pada tubuh manusia. Bakteri lainnya yang berkerabat dengan dengan Bacillus cereus adalah Bacillus anthracis, Bacillus sp, dan Bacillus thuringiensis.

Penelitian-penelitian yang telah dilakukan oleh Kepel, ${ }^{20}$ Sompie, ${ }^{21}$ dan Bahter ${ }^{22}$ terhadap urin pasien pengguna amalgam, mendapatkan bakteri Bacillus termasuk kelompok bakteri yang diisolasi dan diidentifikasi dengan metode uji biokimia. ${ }^{20-22}$ Namun pada penelitian saat itu, uji biokima hanya berhasil mengiden-tifikasi bakteri sampai tingkat genus. Melalui analisis gen $16 \mathrm{~S}$ rRNA, bakteri dapat diidentifikasi sampai tingkat spesies bahkan strain-nya.

Selain itu dapat dipelajari juga hubungan kekerabatan antar spesies bakteri yang memiliki kesamaan dengan sampel.
Bacillus cereus adalah bakteri Gram positif berbentuk basil, dan bersifat aerobik. Bakteri ini saprofitik dengan reservoir utama pada air tawar, air laut, dan tanah. $^{24,30}$ Bacillus cereus dan Bacillus thuringiensis memiliki hubungan fenotipik dan genetik (gen 16S rRNA) yang dekat dengan banyak spesies Bacillus lainnya khususnya Bacillus anthracis, penyebab penyakit antraks. ${ }^{30}$ Bacillus cereus merupakan bakteri yang menyebabkan keracunan makanan (muntah-muntah dan diare) pada manusia. Bakteri ini sering membentuk koloni pada nasi goreng, susu, pasta, daging dan saus. ${ }^{23,24,30}$

Bacillus merupakan jenis bakteri yang sudah lama dikenal resisten terhadap merkuri. Berdasarkan penelitian yang dilakukan sejak 1982, Bacillus merupakan jenis bakteri resisten merkuri yang paling banyak ditemukan di Teluk Minamata. Pada saat itu bakteri yang ditemukan ialah Bacillus subtilis, Bacillus firmus, Bacillus lentus, dan Bacillus badius. ${ }^{31}$ Penelitian selanjutnya menunjukkan bahwa Bacillus cereus, Bacillus megaterium, Bacillus flexus, Bacillus simplex, Bacillus fusiformis, Bacillus sphaericus, Bacillus thuringiensis, dan Bacillus anthracis termasuk dalam bakteri resisten merkuri spektrum luas yang terdapat di Teluk Minamata. ${ }^{32}$ Semakin banyaknya penemuan bakteri Bacillus dengan resistensi merkuri spektrum luas memicu dilakukannya berbagai penelitian tentang pola penyebaran gen pada operon mer dari berbagai bakteri Bacillus.

Operon mer memiliki keunikan, yaitu 
sering terdapat pada komponen genetik yang mobil seperti plasmid dan transposon. ${ }^{29}$ Lokasi gen mer khususnya pada transposon memungkinkan terjadinya transfer gen secara horizontal pada berbagai spesies Bacillus. TnMERI1 merupakan transposon yang membawa gen resisten merkuri spektrum luas, yang pertama kali ditemukan pada Bacillus megaterium MB1. ${ }^{33}$ Berdasarkan penelitian yang dilakukan di India, ditemukan bahwa operon mer Bacillus cereus resisten merkuri spektrum luas yang terdapat di laut memiliki banyak kesamaan, mengindikasikan gen mer (merA dan merB3) yang homolog.

Gen-gen mer ini memiliki kesamaan 99\% dengan gen mer pada TnMERI1 Bacillus megaterium strain MB1 yang terdapat di Teluk Minamata. ${ }^{34}$ Selain di Jepang dan India, Bacillus resisten merkuri yang serupa juga ditemukan di Amerika Serikat, Thailand, Australia, Korea Selatan, Italia, Swiss, Belanda, Taiwan, Afrika Selatan, Irlandia, Swedia dan Meksiko. Penemuan-penemuan ini semakin mendukung teori transfer gen horizontal, yang mengakibatkan banyaknya spesies Bacillus yang memiliki kemampuan resistensi merkuri spektrum luas. ${ }^{33,34}$

Habitat Bacillus yang sebagian besar di laut juga mendukung kemampuan resistensi merkurinya. Lingkungan ekosistem laut yang sering mengalami perubahan $\mathrm{pH}$, suhu permukaan, dan salinitas, menginduksi bakteri-bakteri di dalamnya untuk mampu bertahan dalam lingkungan yang ekstrem dan labil. ${ }^{34,35}$ Dash et al. ${ }^{35}$ meneliti perbedaan kemampuan reduksi merkuri antara Bacillus sp dari tanah dan Bacillus thuringiensis dari laut, dan terbukti bahwa Bacillus yang berasal dari laut memiliki kemampuan yang lebih baik. ${ }^{35}$

Bacillus cereus telah diketahui sebagai bakteri resisten merkuri spektrum luas. Telah dilakukan berbagai penelitian untuk memahami lebih lanjut mekanisme resistensi merkurinya serta penggunaanya untuk bioremediasi. Beberapa penelitian yang dilakukan yaitu menggunakan Bacillus cereus yang diimobilisasi dengan sodium alginat, Bacillus cereus transgenik yang menggunakan plasmid dari Bacillus thuringiensis, serta isolasi Bacillus cereus dari spons Polymastia janeirensis dan dari lumpur limbah industri klor-alkali lokal. Keseluruhan hasil penelitian yang dilakukan menunjukkan hasil yang memuaskan dalam meremediasi merkuri. Dash et al. ${ }^{355}$ juga menemukan bahwa molekul eksopolimer (EPS) pada biofilm Bacillus cereus meningkatkan efektivitas volatilisasi merkuri oleh bakteri, melalui perannya pada trapping merkuri ekstrasel dan membantu kinerja dari operon mer pada bakteri. Berbagai penelitian ini telah membuktikan bahwa Bacillus cereus di lingkungan, sangat berpotensi untuk digunakan pada bioremediasi. ${ }^{36-40}$

Seperti yang telah dijelaskan sebelumnya, berbagai spesies Bacillus memiliki karakteristik fenotip dan genetik yang sangat mirip. Namun dalam hal kemampuan resistensi merkuri, lingkungan sekitar dapat berpengaruh. Selama ini telah terbukti bahwa Bacillus cereus yang berasal dari air dan tanah merupakan bakteri yang sangat berpotensi untuk digunakan dalam bioremediasi lingkungan tercemar merkuri. Penelitian ini telah berhasil mengidentifikasi bakteri resisten merkuri secara lebih akurat dari penelitian sebelumnya. ${ }^{30-32}$ Dengan melihat penelitian ini dimana Bacillus cereus resisten merkuri diisolasi dari urin pasien pengguna amalgam, penelitian selanjutnya dapat dikembangkan mengetahui potensi bakteri ini untuk bioremediasi lingkungan tercemar merkuri.

\section{SIMPULAN}

Berdasarkan hasil penelitan ini, bakteri resisten merkuri yang diisolasi dari urin pasien pengguna amalgam ialah Bacillus cereus. Bakteri ini tidak termasuk dalam flora normal tubuh manusia, dan memiliki hubungan kekerabatan yang dekat dengan Bacillus anthracis, Bacillus sp, dan Bacillus thuringiensis.

\section{SARAN}

Pada penelitian selanjutnya dapat 
dipelajari perbandingan daya reduksi merkuri serta gen mer antara Bacillus cereus yang berasal dari lingkungan dan yang berasal dari tubuh manusia. Penelitian lebih lanjut juga dapat dilakukan untuk mempelajari potensi Bacillus cereus dari pasien pengguna amalgam dalam bioremediasi lingkungan tercemar merkuri.

\section{DAFTAR PUSTAKA}

1. World Health Organizations. Ten chemicals of major public health concern [Internet]. 2017 [cited 2017 Aug 21]. Available from: http://www.who.int/ipcs/assessment/public _health/chemicals_phc/en/

2. World Health Organizations. Mercury and Health [Internet]. 2017 [updated 2017 March; cited 2017 August 21]. Available from: $\quad$ www.who.int/mediacentre/fact sheets/fs361/en/

3. Bernhoft RA. Mercury Toxicity and treatment: a review of the literature. Journal of Environmental and Public Health. 2012.doi: 10.1155/2012/460508

4. Rice KM, Walker EM, Wu M, Gillette C, Blough ER. Environmental Mercury and Its Toxic Effects. J Prev Med Public Health. 2014;47(2):74-83.

5. Fatimawali. Buku Ajar Toksikologi Detoksifikasi Merkuri. Manado: Unsrat Press, 2016.

6. Al-Saleh I, Al-Sedairi A. Mercury ( $\mathrm{Hg})$ burden in children: The impact of dental amalgam. Sci Total Environ. 2011; 409(16):3003-15.

7. Richardson GM, Wilson R, Allard D, Purtill C, Douma S, Gaviere J. Mercury exposure and risks from dental amalgam in the US population, post-2000. Sci Total Environ. 2011;409(20):4257-68.

8. Mudawi M, Hagga M, Mousa A, Khir M. Toxicity of mercury asscociated with dental amalgam filling. Int $\mathbf{J}$ Pharmacol Toxicol. 2014;4(1):5-10.

9. American Dental Association. Statement on Dental Amalgam [Internet]. 2017 [cited 2017 September 05]. Available from: http://www.ada.org/en/about-the-ada/adapositions-policies-andstatements/statement-on-dental-amalgam

10. Anang DY, Mariati NW, Mintjelungan CN. Penggunaan bahan tumpatan di Rumah Sakit Gigi dan Mulut PSPDG Fakultas Kedokteran Unsrat pada tahun
2014 [Skripsi]. Manado: Universitas Sam Ratulangi; 2014.

11. Profil Puskesmas Bahu Tahun 2016.

12. Azevedeo B, Furieri L, Pecanha F, Wiggers G, Vasallo P, Simoes M, et al. Toxic effects of mercury on the cardiovascular and central nervous systems. Journal of Biomolecular and Biotechnology. 2012. doi:10.1155/2012/949048.

13. Figueiredo $\mathbf{N}$, Canario $J$, Duarte $A$, Serralheiro M, Carvalho C. Isolation and characterization of mercury-resistant bacteria from sediments of Tagus estuary (Portugal): Implications for environmental and human health risk assessment. J Toxicol Environ Health, Part A.2014:77(13):155-68.

14. Virsek M, Hubad B, Lapanje A. Mercury induced community tolerance in microbial biofilms is related to pollution gradients in a long-term polluted river. Aquatic Toxicol. 2013;144-145:208-17.

15. Giovanella P, Cabral L, Bento F, Gianello C, Camargo F. Mercury (II) removal by resistant bacterial isolates and mercuric (II) reductase activity in a new strain of Pseudomons sp. B50A. New Biotechnol. 2016;33(1):216-23.

16. Mahbub K, Krishnan K, Megharaj M, Naidu R. Bioremediation potential of a highly mercury resistant bacterial strain Sphingobium SA2 isolated from contaminated soil. Chemosphere. 2016;144:330-7.

17. Dash H, Mangwani N, Das $S$. Characterization and potential application in mercury bioremediation of highly mercury-resistant marine bacterium Bacillus thuringiensis PW-05. Environ Sci Pollut Res. 2014;21(4):642-53.

18. Pundogar, Sittie R, Bautista, Jing R, Teves F. Prevalence of mercury-resistant and antibiotic-resistant bacteria found in dental amalgam. Int. Res. J. Biological Sci. 2014;3(4):1-4.

19. Kepel B, Fatimawali. Penentuan jenis dengan analisis gen 16s rRNA dan uji daya reduksi bakteri resisten merkuri yang diisolasi dari feses pasien dengan tambalan amalgam merkuri di Puskesmas Bahu Manado. Jurnal Kedokteran Yarsi. 2015;23(1):045-055.

20. Kepel R. Isolasi bakteri resisten merkuri pada urin pasien dengan tumpatan amalgam di Puskesmas Tikala Baru [Skripsi]. Manado: 
Universitas Sam Ratulangi; 2016.

21. Sompie I. Isolasi bakteri resisten merkuri pada urin pasien dengan tumpatan amalgam di Puskesmas Paniki Bawah [Skripsi]. Manado: Universitas Sam Ratulangi; 2016.

22. Bahter J. Isolasi bakteri resisten merkuri pada urin pasien dengan tumpatan amalgam di Puskesmas Tuminting [Skripsi]. Manado: Universitas Sam Ratulangi; 2016.

23. Cowan MK. Microbiology: A Systems Approach (3rd ed). Miami: McGraw-Hill, 2012.

24. Carroll K, Morse S, Mietzner T. Miller S. Jawetz, Melnick \& Adelberg's Medical Microbiology (27th ed). New York: McGraw-Hill Lange, 2016.

25. Tremblay J, Singh K, Fern A, Kirton E, He S, Woyke T, et al. Primer and platform effects on 16s rRNA tag sequencing. Front Microbiol. 2015;6:771.

26. Yarza P, Yilmaz $P$, Pruesse E, Glockner F, Ludwig W, Schleifer KH. Uniting the classification of cultured and uncultured bacteria and archaea using 16s rRNA gene sequences. Nature Rev Microbiol. 2014;12(9):635-45.

27. Fadrosh D, Ma B, Gajer P, Sengamalay N, Ott S, Brotman R, et al. An improved dual-indexing approach for multiplexed 16s rRNA gene sequencing on the Illumina MiSeq platform. Microbiome. 2014;2(6).

28. Stack Exchange. Biology. What causes the variable/concerved structure in the $16 \mathrm{~s}$ rRNA gene? [Internet]. 2017 January 23 [cited 2017 September 19]. Available from: https://biology.stackexchange.com/ questions/54823/what-causes-the-variableconserved-structure-in-the-16s-rrna-gene.

29. Dash H, Das S. Bioremediation of mercury and the importance of bacterial mer genes. Int Biodeterior Biodegradation.. 2012;75: 207-213.

30. Bottone E. Bacillus cereus, a volatile human pathogen. Clin Microbiol Rev. 2010;23(2):382-98.

31. Nakamura K, Silver S. Molecular analysis of mercury-resistant Bacillus isolates from sediment of Minamata Bay, Japan. Appl Eviron Microbiol. 1994;60(12):4596-99.
32. Narita M, Chiba $K$, Nishizawa $H$, Ishii $H$, Huang C, Kawabata Z, et al. Diversity of mercury resistance determinants among Bacillus strains isolated from sediment of Minamata Bay. FEMS Microbiology Letters. 2003;223(1):73-82.

33. Matsui K, Satoshi Y, Narita M, Chien MF, Phung L, Silver S, et al. Mercury resistance transposons in Bacilli strains from different geographical regions. FEMS Microbiology Letters. 2016;363(5).

34. Kannan SK, Mahadevan S, Krishnamoorthy R. Characterization of mercury-reducing Bacillus cereus strain isolated from the Pulicat Lake sediments, south east coast of India. Arch Microbiol. 2006;185(3):202-11.

35. Dash H, Das S. Bioremediation potential of mercury by bacillus species isolated from Marine Environment and Wastes of Steel Industry. Bioremediation Journal. 2014;13:204-12.

36. Sinha A, Pant K, Khare S. Studies on mercury bioremediation by alginate immobilized mercury tolerant Bacillus cereus cells. Int Biodeterior Biodegradation. 2012;71:1-8.

37. Dash H, Das S. Bioremediation of inorganic mercury through volatilization and biosorption by transgenic Bacillus cereus BW-03(pW-05). Int Biodeterior Biodegradation. 2015;103:179-185.

38. Santos-Gandelman J, Cruz K, Crane S, Muricy G, Giambiangi-deMarval M, Barkay T, et al. Potential Application in Mercury Bioremediation of a Marine Sponge-Isolated Bacillus cereus strain Pj1. Curr Microbiol.2014;69(3):374-80.

39. Ghoshal S, Bhattacharya P, Chowdhury R. De-mercurization of wastewater by Bacilluus cereus (JUBT1): Growth kinetics, biofilm reactor study and field emission scanning electron microscopic analysis. Journal of Hazardous Materials. 2011;194:355-61.

40. Dash H, Basu S, Das S. Evidence of mercury trapping in biofilm-EPS and mer operonbased volatilization of inorganic mercury in a marine bacterium Bacillus cereus BW201B. Arch Microbiol.2017;199(3):445-55 